\title{
GENERALIZED MODEL OF INTEGRATED TECHNOLOGY OF MEDICAL STUDENTS' INDIVIDUAL WORK MANAGEMENT IN LEARNING A FOREIGN LANGUAGE
}

\author{
К. Б. Олексій, Т. В. Саварин, І. І. Ворона \\ ДВНЗ «Тернопільський державний медичний університет \\ імені І. Я. Горбачевського МОЗ України»

\section{УЗАГАЛЬНЕНА МОДЕЛЬ ІНТЕГРАТИВНОЇ ТЕХНОЛОГІЇ УПРАВЛІННЯ САМОСТІЙНОЮ РОБОТОЮ СТУДЕНТІВ-МЕДИКІВ ПРИ ВИВЧЕННІ ІНОЗЕМНОЇ МОВИ}

\begin{abstract}
Different approaches to the study of the system of students' individual work management have been analyzed. The peculiarity of the proposed integrative technology of students' individual work management is that the management effectiveness is achieved through the organization of the students' individual work with diagnostic objectives, the achievement of which is subject to a clear description and definition.

Structural components of integrated technology are: goals, content, methods, organizational forms and functional components.

It has been proved that the effectiveness of management of students' individual work depends on the goals and methods of achieving them; internal motivation and cognitive interests of students; quality of the content aspect of educational information for self-study; creation of favorable conditions for self-realization of a student; the methodological provision of the discipline, its precise planning, organization and management, student's free time; the competent use of various forms of current and periodic control.

Integrated technology develops intellectual and creative students' abilities, helps to make decisions. This circumstance is especially important, as in modern science, there is an increasingly evident tendency to the synthesis of knowledge, to the awareness and disclosure of the collectivity of cognition objects.
\end{abstract}

Key words: students' individual work; technology management; management process; approach; methods.

Анотація. У статті проаналізовано різні підходи до вивчення системи управління самостійною роботою студентів. Особливість запропонованої інтегративної технології управління самостійною роботою студентів полягає в тому, що ефективність управління досягається за рахунок організації СРС з діагностично поставленими цілями, досягнення яких піддається чіткому опису та визначенню.

Структурними компонентами інтегративної технології є: цілі, зміст, методи, організаційні форми і функціональні компоненти. Було доведено, що ефективність управління СРС залежить від цілей і способів їх досягнення; внутрішньої мотивації і пізнавальних інтересів студентів; якості змістовного аспекту навчальної інформації для самостійного вивчення; створення сприятливих умов для самореалізації студента; методичного забезпечення навчальної дисципліни, від її чіткого планування, організації та управління, ретельного вивчення вільного часу студента; від компетентного використання різноманітних форм поточного та періодичного контролю.

Інтеграційна технологія розвиває інтелектуальні та творчі здібності студентів, допомагає приймати масштабні рішення. Дана обставина особливо важлива, оскільки в сучасній науці все більш очевидна тенденція до синтезу знань, до усвідомлення і розкриття спільності об’єктів пізнання.

Ключові слова: самостійна робота студентів; технологія управління; процес управління; підхід; методи.

(c) K. B. Oleksii, T. V. Savaryn, I. I. Vorona 
Introduction. The main task of modernization of higher education is to create a flexible and effective management system. Current pedagogical practice pays insufficient attention to management of students' individual work for development of students' professional and subject competence. In this regard, students do not have a focused interdisciplinary work for development of self-organization and selfregulation skills in students' individual work focused on their future profession. These skills do provide an adequate coping with professional tasks, taking the initiative and displaying personal qualities. The organization of management should be aimed at attaining the most advantageous result.

The aim - to analyze the peculiarities of the integrated technology of medical students' individual work management, namely its structural components.

Theoretical framework. The analysis of the national and world literature (M. R. Grachev, E. M. Korotkoe, O. T. Lebedev, P. A. Druker, A. A. Faiol) enables developing the basis of students' individual work management. The concept of the process approach allows considering the students' individual work management as a process containing a number of continuous interrelated functions, which form the basis for effective teacher management. The systematic approach involves development of the main system of interdependent components, which is capable to adapt to the external changes.

The situational approach provides a choice of methods and techniques of learning to achieve goals in each specific situation under some circumstances. The situational approach involves awareness of verified and effective means of management, ability to properly assess and predict the situation, to set priorities, as well as to use a variety of methods and techniques reasonably.

Most international researchers emphasize that management is a process of planning, organizing, motivating, regulating and controlling, which is necessary to achieve the goals of organization.

According to A. Fayol, to manage means to predict and plan, organize, dispose, coordinate and control. Planning is making a decision on goals and how to achieve them. It should be performed because of uncertainty of the future. The management involves development of a multi component structure: people's activities, definite tasks. The motivation is necessary for effective and efficient implementation of human activities. The control is intended to ensure effectiveness of an activity.
There are three aspects of management control: establishment of standards, evaluation and comparison, correction in case of deviation from the plan, precise definition of the aims to be achieved within a definite period of time. Then the result is evaluated, it is actually achieved over a certain period of time, and its comparison with the expectable indicators is carried out. At the third stage, the measures are taken to correct significant deviations from the plan. In order to make the aims more real in particular conditions, revision could be performed. All these management functions are combined by importance of decision making and its implementation in a communication, which is an information sharing process.

The management process emphasizes the interrelationship of the management function; it distinguishes this one from a system approach, which focuses on the correlation of individual components of management as well as the dependence on the environment. Some researchers characterize it as a process of purposeful influence of a management subject on a control object for attaining certain results [2].

Teacher's management is a complex system that provides students with processing of professionally significant information and training of specialists with professional self-management skills. The management system consists of components that are interconnected through direct and inverse relationships; it is a single whole, in which relations with the external environment are present. To develop an effective management it is necessary to establish an optimal relation of its components, which ensures the efficiency and timeliness of achieving goals.

Theoretical and methodological analysis of the research problem allows substantiating and developing a model of the integrated technology of students' individual work management. The cyclical nature of learning management should be noted; it is aimed at processing the content of a foreign language and special disciplines, according to the curriculum, and implemented for achieving goals by means of methods, forms and means [5].

The integrated technology of students' individual work management is a system of techniques, approaches, methods and means that provide realization of learning content using the interdisciplinary knowledge, cognitive activity as well as by development of creative thinking aimed at professional and subject competence development.

Thus, the technique is unique because the effectiveness of management is achieved by organization of students' 
individual work with diagnostically set aims, the achievement of which can be clearly described and defined. The structural components of the integrated technology of students' individual work management in detail are presented below.

The objectives of management influence on the entire course of the students' individual work join the content, methods, organizational forms and control that largely determines the accomplishment of pedagogical activities. The objectives of management are determined by indicating the final state of the object in the form of a precise list of features. Meanwhile, current practice has no clear definition of the learning purpose that could be used for comparative analysis. The concept of purpose is often substituted by the concepts of content, learning topics, components of educational process; there are no (or they are very inadequate) criteria for the quality of learning material; the didactic purposes are substituted by planning of teacher's activity, while the aim of the pedagogical process is not the specific behavior of a teacher, but positive changes in students' training [1].

The purposes are completely planned and assessable results of educational and cognitive actions of students for acquiring knowledge, development and improvement of skills and abilities.

The student must master the system of methods for individual work, ways of analyzing the content of educational texts, their memorization during mental processing, methods of searching for new information and using it to perform the tasks. Thus, the most effective way of setting the objectives is to formulate them through learning outcomes expressed in students' actions at various levels of digesting a particular discipline as well as levels of their activities. The planned objectives evaluate the results of joint activities of the subjects of learning for acquisition of knowledge, development of skills and abilities.

The content is professional educational information, which involves the system of problem and cognitive tasks-assignments and structurally logical schemes that ensure development of professional and learning skills and is presented by a teacher or by technical means. The information should conform to the tasks for specialists training and contain the most recent material.

For effective implementation of a technology for each type of study, the methods and means of management and control should be reasonably selected. The activities of a teacher and student are realized through the use of various methods, means and forms. The means of learning is a material or ideal object used by a teacher or a student to acquire knowledge. Such means include specially developed didactic materials, as well as training and assessment programs, tests, audiovisual materials. The method is an educational category, a complex of techniques, methods and means for gaining a certain pedagogical aim, i.e. problem solving tasks, discussion, role-playing and business games, research methods and methods of programmed control, etc. The technique is a way of performing something. Organizational forms as one of the structural components of management technology are a series of interrelated in time and process types of activities (individual students' class work - extracurricular individual work of students - consultation - testing correction - diagnostics) under supervision of a teacher that involve interpersonal interaction of the subjects of learning.

The study of the features of management subsystem functioning is essential, since this area of research needs a focused attention of the researchers. It is the most important factor of the effective use of students' time and improvement of the quality of specialist's training. In this regard, the search of methods and ways for effective management of students' independent work is topical.

The result of individual work planning by medical university students is the development and approval of guidance with regards to the type of educational material for individual work on a certain discipline taking into account classroom and extracurricular work, technology of students' individual work as well as forms of management of this activity. In our opinion, such a document should include issues related to the assessment of the level of linguistic readiness of freshmen, assistance in organization of students' individual work on foreign languages and methodological support of a definite discipline, for the students' individual work as well. Many pedagogues highlight the importance of such a document.

The students' individual work should be accurately planned for achievement of the goals set. The planning is the initial stage of any learning activity and determines the trends and course of students' individual work development, since in the presence of accurate working programs, this type of educational activity is organized more effectively, the advancement from the set goals to the predicted result is presented as well. This process is best implemented together with a student, taking into account their interests and needs. 
Planning is a complex multi-parameter task, in which the importance of implementation of students' individual work on all subjects in a semester (academic year) under the restrictions on the total weekly (daily) time of involvement of a student into academic activities. Curricula of the disciplines studied in the upcoming academic year/semester, are the basis for planning of students' independent work. Such work programs should be presented by the relevant Departments and Curriculum offices. A group leader receives an abstract from the curriculum and a schedule of classes and informs this information to each group member.

A time-honored pedagogical practice proves that the lack of individual work skills prevents students from making this educational activity effectively. Moreover, the inability to plan their study time, ignorance and breaching the hygiene of mental labor, lack of experience in noting lecture material, making schemes and theses, no skills in working with library catalogs and scholarly apparatus may be a trouble.

Students' individual work on information processing involves the sequence of actions: planning a professionally focused students' individual work, primary digesting of information, understanding, using, analysis, information synthesis, processing, monitoring and assessment. In these actions a particular goal is realized, achievement of which is essential for advancement to the subsequent actions.

To improve the efficiency of the learning and pedagogical process, students should be encouraged to follow an evidence-based daily and weekly rhythm of work and rest. Thereby, it is important to work out an alternation of subjects and types of studies so that the most difficult subjects took place in the middle of the week.

The teacher's organization of a professionally focused students' individual work includes making decisions - setting the task, gathering information on the methods of performing it, critical analysis of alternatives, and implementation of the decisions: reasoning the choice of techniques, setting tasks for students and explanation how to achieve it, setting individual and group tasks and coordination of actions to perform them.

The organization of students' individual work should provide a successful learning both a foreign language and special disciplines, encourage expansion, consolidation and deepening of the knowledge gained in the classroom; active acquisition of new knowledge; development of a creative approach to solving problems; development of self-realization of student's individuality; development of practical skills in solving case problems [6].

Foreign language lessons do not involve the course or diploma papers, as well as reports on practice. Therefore, the forms of teaching a foreign language in medical universities have its own peculiar features. The most common forms of students' individual work management are: preparation for practical classes; homework; writing reports, essays; preparation for a role-playing business game and drawing conclusions on its results; preparation for tests; preparation for credit tests.

The effectiveness of the students' individual work can be achieved under the following conditions: purposefulness and reasonable activity in search for the most reasonable and effective ways and forms of studying; systematic and consistent work; rational organization of individual work, accurate time planning, availability of necessary training and teaching materials. Combining the efforts of a teacher and a student for searching the truth is important in education. The ability to prioritize and highlight the discussion points in the process of solving a problem stimulates the attention and mental activity of students, makes a creative environment.

Management allows regulating a professionally focused students' individual work, to identify and eliminate deviations from the plan, to stimulate actions and motivation to achieve results in accordance with the intended purposes. The management process of students' individual work is of a complete cyclical nature and aims at ensuring the functioning and development that is advancement of the system to a new qualitative state. The integrated technology of students' individual work management in learning a foreign language and special disciplines ensures development of new integral abilities in students that are not inherent for the subjects in their disunity.

Since students prepare for their future professional practice, the students' individual work should become a reflection of such activity, i.e. include all types and forms related to it. In addition, each type of individual work is determined by the specifics of the content of learning material and depends on the experience of mastering it by students. The successful education directly depends on the clarity of setting purposes and tasks, individual approach to studying, importance of learning material for future professional practice, the use of innovative educational technologies, prompt feedback and timely corrections taking into account 
characteristic features of a group or an individual, as well as providing students with relevant methodical materials.

The assessment is a supervisory function, by means of which a teacher determines the correctness of a particular learning technique and considers the necessity for its adjustment.

The assessment is an integral and very serious component of the students' individual work, aimed at objective determination of the level of students' mastering material on foreign language at each stage of the development of students' speaking skills. The main functions of the assessment are its ability to help students to consolidate and systematize their knowledge, to facilitate development of appropriate skills and abilities, thinking, self-assessment, and finally, it enables a teacher to know the personality of a student better [4].

The assessment not only regulates the process of students' individual work, but also has a positive impact on its type and effectiveness. The educational significance of the assessment as an important motivation for a knowledge quality improvement and a successful career in the future should be emphasized.

Oral questionnaire is one of the methods of assessment at classrooms learning in medical universities. Its effectiveness depends on the performance of the whole group in this process; since the work with other students receives less time. Oral questionnaire allows repeating studied topics and solidify the most difficult units.

Translation or retelling of texts, making story by a drawing, etc. can be an assessment task. Besides the test, the individual work should be emphasized, the purpose of which is to reveal the ability of students to creatively apply their knowledge. Individual work should be checked not only according to the parameters of correct result achieving, but also by evaluation of logical correctness and creative approach to solving the problem. Translation exercises are important in teaching a foreign language speaking. At the beginning of acquaintance with a new lexical or grammatical material, they are very useful and helpful, because essentially they are testing and explanatory. "They show whether the material is fully presented in the class and whether the students have fully understood the information they need" [3]. After the material is understood, work on bringing skills to automatism begins. During this period, it is advisable to use question-answer type exercises, as well as retellings and tasks, which help develop a language guess.
Tests provide a better objectivity in the assessment of knowledge. Tests in a foreign language allow more widely and completely covering the studied material, taking into account its complexity. The main advantage of test assessment compare to traditional forms is its objectivity, involvement of a larger number of students, as well as saving study time.

In teaching a foreign language, due attention should be paid to self-assessment, since it is a method of 'immunity' against mistakes and a way of mastering a foreign language. On the basis of self-assessment development, manifested in the style of error correction, the level of speaking proficiency can be evaluated.

The management of students' individual work on a foreign language performs the following functions:

1. Organizational and managing function provides rational timing of individual work; planning, organization, based on the standards of its labor intensity and management of individual work.

2. The learning function of assessment helps to identify new concepts, highlight the main and secondary issues, deepen the knowledge and ideas, reflection of acquired knowledge, creative understanding of information.

3. The educational function of assessment advantages in development of responsibility, discipline, will, selfconfidence, willingness for continuous scientific and professional self-improvement.

4. The testing and diagnostic function includes determination of speaking knowledge and skills development, monitoring the degree of development of knowledge and skills in students' individual work, identifying the quality of mastering educational material, diagnosing students' ability to use their knowledge in non-standard situations, affirmation of the effectiveness of individual work management.

5. The developmental function is for stimulation of attention, memory, thinking, and psychological mobilization of intellectual development and selfenrichment of students, motivation of cognitive activity and cognitive independence, development of skills to analyze, synthesize and structure speaking.

6. The motivating and stimulating function is for encouragement of positive learning motivations, stimulation of development of abilities to achieve success, motivation to get a 'home free' grade as a result of the systematic executing of individual work, the possibility to receive moral or material encouragement.

7. Corrective function is for adjustment of students' educational activities through consultation and 
selection of the most rational forms and types of students' individual work.

Conclusions and Prospects for Research. Integrated technology develops intellectual and creative students' abilities, helps to make decisions. This circumstance is especially important, as in modern science, there is an increasingly evident tendency to the synthesis of knowledge, to the awareness and disclosure of the collectivity of cognition objects.

The effectiveness of management of students' individual work depends on the goals and methods of achieving them; internal motivation and cognitive

\section{List of literature}

1. Володарская И. А. Проблема целей обучения в современной педагогике / И. А. Володарская, А. Митина. М. : Изд-во МГУ, 1985. - С. 72.

2. Лебедев О. Т. Основы менеджмента / О. Т. Лебедев, А. В. Каньконьская. - СПб. : Издат. дом, 1998. - С. 82.

3. Харламов И. Ф. Педагогика : учеб. пособие / И. Ф. Харламов. - М., 1990. - С. 200.

4. Якобсон П. М. Общение людей как социально-психологическая проблема / П. М. Якобсон. - М. : Знание, 1973. - C. 40.

\section{References}

1. Volodarskaya, I.A., \& Mitina, A. (1985). Problema tseley obuchenyia $v$ sovremennoy pedagogike [The problem of learning objectives in modern pedagogy]. Moscow: Izd-vo $M G U$ [in Russian].

2. Lebedev, O.T., \& Kankonskaya, A.V. (1998). Osnovy menedzhmenta [Management basics]. SPb. Izdat. Dom [in Russian].

3. Harlamov, I.F. (1990). Pedagogika. Ucheb. Posobie [Pedagogy. Textbook allowance]. Moscow [in Russian]. interests of students; quality of the content aspect of educational information for self-study; creation of favorable conditions for self-realization of a student; the methodological provision of the discipline, its precise planning, organization and management, student's free time; the competent use of various forms of current and periodic control.

Prospects for further research: development of intellectual and creative abilities of the students, improvement of the quality of the content aspect of educational information, creation of favorable conditions for the student's self-realization.

5. Hatch E. Discourse and Language Education / E. Hatch. - Cambridge : Cambridge University Press, 1992.

6. Platt E. Task engagement: A turning point in foreign language development / E. Platt, F. B. Brooks // Language Learning. - 2002. - Vol. 52. - P. 365-400. doi: 10.1111/00238333.00187.

4. Yakobson, P.M. (1973). Obshenie lyudey kak sotsialnopsihologicheskaya problema [Communication of people as a socio-psychological problem]. Moscow: Znanie [in Russian].

5. Hatch, E. (1992). Discourse and Language Education. Cambridge: Cambridge University Press.

6. Platt, E., \& Brooks, F.B. (2002). Task engagement: A turning point in foreign language development. Language Learning, 52, 365-400. doi: 10.1111/0023-8333.00187.

Received 10.04.19 Recommended 15.04.19

E-mail address for correspondence: oleksij@tdmu.edu.ua 